\title{
Earnings Management using Other Comprehensive Income Items: A Multi-Case Study on Chinese Listed Companies
}

\author{
Xiaofang Zhao ${ }^{1}$, Kuan Zhao ${ }^{2}$, Wei Wei ${ }^{3}$ \\ ${ }^{1}$ Beijing Jiaotong University, Beijing, China \\ ${ }^{2}$ Zhong De Securities Company Limited, Beijing, China \\ ${ }^{3}$ International School of Management (Frankfurt/Main), Frankfurt/Main, 60598
}

Keywords: Other Comprehensive Income; Earnings management; Multi-case study.

\begin{abstract}
This study investigates those other comprehensive income items reclassified and recognized outside of profit or loss as a tool for earnings management based on multi-case study methodology. Through the analysis of a series of samples of Chinese listed companies, we find some positive evidence that managers regard OCI items as complementary to earnings management, such as concealing losses, adjusting asset liability ratio, and smooth earnings.
\end{abstract}

\section{Introduction}

The International Accounting Standards Board (IASB) formally introduced the concept of comprehensive income (OCI) in the revised version of IAS1- Presentation of Financial Statements issued in 2007. In recent ten years, the Ministry of finance has repeatedly revised the other comprehensive income guidelines. Before 2007, the concept of OCI in China was missing, and the records of such items were confused. After 2007, the China Accounting Standards (CAS) No. 30 issued a regulation for the disclosure of owner's equity table of listed companies, one of which is gain and loss directly counted into owner's equity, which laid the foundation for OCI in the future. In 2009 the Ministry of Finance announced the Accounting Standard for Business Enterprises Interpretations No.3, the first criterion definition of the other OCI items, and requires the enterprises add other "OCI" and "comprehensive income" two subjects below earnings per share in the profit statement. In December 2009, the Ministry of finance also made a detailed delineation of the way and the contents of OCI need to be disclosed, and asked enterprises to disclose OCI items in statement of changes in equity. Based on that, the Ministry of Finance solicited opinions on the presentation of financial statements, and standardized the items and ways of OCI in the income statement in 2012.

After the reform of CAS in 2014, the CAS incorporate comprehensive income into the main text while absorb relevant contents such as accounting standards interpretation and cases, which indicates the continuous convergence with the new International Financial Reporting Standards (IFRS). And the revision of OCI is a major highlight of the reform.

Other comprehensive income, the difference between net income and comprehensive income, represents the certain gains and losses of the enterprise not recognized in the P\&L Account. OCI items are further classified by nature and grouped into two categories according to CAS -those items that will or will not subsequently be recognized outside profit and loss when specific conditions are met. There are five examples in CAS that will be required or permitted to reclassified, including the share of OCI of associates, gains and losses on remeasuring available-for-sale financial assets, gains and losses on reclassifying held-to-maturity investments into available-for-sale financial assets, the effective portion of gains and losses on hedging instruments in a cash flow hedge and exchange differences from translating functional currencies into presentation currency.

The contributions of this study are as follows. Firstly, this article extends research achievements of influence mechanism of OCI in earnings management. Secondly, this study provides relevant evidence to current debates over reconsideration of the current recycling rule in order to reduce the possibility of earnings management by standard setting bodies-the Ministry of Finance. Thirdly, this 
study also contributes to those business stakeholders that need to evaluate management performance, such as shareholders, investors, analysts and directors since earnings can be altered through using OCI.

The purpose of this article is to investigate OCI as a tool for earnings management with multi-case study method and it is divided into six parts to start on. Sections 2 to section 5 present the four cases and analysis of OCI and earning management. This article will not unfold the share of OCI of associates because it is similar to the above four types and needed to be combined with the change in long-term equity investment. Finally, section 6 concludes this paper and identifies areas for future study.

\section{Bailout fund and OCI}

In the 2015 China's stock market Crash, 21 large securities firms actively participated in the Bailout Stock Markets since July. Guoxin Securities, for example, has twice spent a total fund of 890 million Yuan by carrying out the business of exchange of income and other rescue with China Securities Finance Corporation Limited, which funds were stuck at high stage. The stock market went down further in 2016 and the average loss has exceeded 10\%, as of the beginning of March.

However, the first quarterly report of 2016 showed that securities firms generally performed well from the profit indicators, as shown in Table 1. The first reason is that the bailout fund was classified into available-for-sale financial assets by securities firms, whose fair value changes was directly recognized in OCI but not in profit and loss. Secondly, as for impairment of assets, it indicates that the available-for-sale financial asset has been impaired if there is a serious or non-temporary decline in the fair value, and the impairment loss should be recognized. However, almost all securities firms regarded it as non-grave and temporary downturn and did not recognize any impairment loss.

Although securities firms managed to classify the financial assets as available-for-sale financial assets, confirm them as temporary decline, and reach the aim of no effects on profit or loss for the current period, they "hidden" the losses. Besides, gains and losses on remeasuring available-for-sale financial assets belong to those OCI that will be reclassified to profit and loss in the subsequent periods, and the performances of securities firms had hidden mines. As shown in Table 1, although the net income attributable to shareholders of the parent company of securities listed companies in A-share market in the first quarter of 2016 was an average of 721 million Yuan, due to the changes in the fair value of available-for-sale financial assets, the total comprehensive income attributable to the shareholders of the parent company was only 20 million Yuan.

Table 1: The average of some items in the consolidated income statement of securities listed companies in A-share market

\begin{tabular}{l|c}
\hline In millions & Q1 2016 \\
\hline Net income & 721 \\
\hline Net income attributable to shareholders of the parent company & 656 \\
\hline Total other comprehensive income (loss), net of tax & $(648)$ \\
\hline Gains and losses on remeasuring available-for-sale financial assets & $(630)$ \\
\hline Comprehensive income attributable to the shareholders of the parent company & 20 \\
\hline
\end{tabular}

Data Sources: Wind database.

Therefore, when analyzing the performance of listed companies in securities industry, especially in the context of bailout, it's recommended that the impact of OCI and indicators of comprehensive income (for example, comprehensive income per share, etc.) should be taken into consideration. In addition, users of accounting information should distinguish OCI from specific items, and use relevant information to make decisions in a targeted way (Yang, 2016).

\section{Available-for-sale financial assets and OCI recognized outside}

It is difficult for the information users to distinguish business income and investment income and also to identify proper methods of investment risk control, that is, what percent the enterprise holds is 
reasonable and whether managers vanish financial statements through abnormal sales and purchase (Wang, 2012). It has been proved that US banks sold AFS securities to smooth income and "big bath" (Barth et al., 2014).

Shanghai Belling is a listed company engaged in the manufacturing and trading of integrated circuits. In 2015, 64.01 million tradable shares, representing $6.19 \%$ of the total share capital of Hua Hong Semiconductor Co., Ltd. which was held by Shanghai Belling's subsidiary-Hylintek Limited, as available-for-sale financial assets, were transferred to United International Limited at a price of $¥ 11.1245$ per share. The total amount of transaction was 712.08 billion Yuan, and the income on investment is 0 because the stock transfer price is equal to the initial book investment cost.

As shown in Table 2, the effects of the transaction on the Shanghai Belling consolidated financial statements were as follows: the available-for-sale financial assets decreased by 517 million Yuan, the OCI increased by 163 million Yuan, cash and cash equivalents increased by 712 million Yuan. More importantly, for Hylintek Limited, the subsidiary with tight capital requirements for bank borrowings, OCI (in this case, it meant balance sheet items), negative balance, was reversed by this transaction at current period, making its net assets increased by approximately 33\%, which in turn helped it to pass the examination through net assets indicators and asset liability ratio to obtain bank loans. As a result, Hylintek Limited got new RMB loans at 8.36 million in 2015.

Table 2: Financial data of Shanghai Belling and its subsidiary Hylintek Limited

\begin{tabular}{l|c|c}
\hline In millions & 2015 & 2014 \\
\hline Shanghai Belling consolidated statement items & & \\
\hline Available-for-sale financial assets & 158 & 637 \\
\hline Other comprehensive income (loss) & - & $(163)$ \\
\hline Net fair value gain on available-for-sale financial assets & 163 & $(163)$ \\
\hline Hylintek Limited & & \\
\hline Net assets & 732 & 551 \\
\hline
\end{tabular}

Data Sources: Shanghai Belling 2015 Annual Report.

It shows that the gains and losses on remeasuring available-for-sale financial assets not only can be reclassified in the future periods to release reclamation or erosion of profit or loss, but also can be reversed negative balance of OCI by disposure to achieve the intended effect of increasing net assets.

\section{Exchange differences}

It cannot be neglected that the potential impact of reclassification upon profit or loss once the prescribed conditions are met in subsequent periods if there is a large amount of exchange differences from translating functional currencies into presentation currency incurred by the enterprises involved in overseas operations in the current period.

For example, Blue Focus is the biggest communications group in China and the eighth largest in the world through a series of mergers and acquisitions, which international business includes Vision7 International Inc., We Are Very Social, Financial PR Group, and Fuse Project. In 2016, international business revenue accounted for $37.71 \%$ of the total revenue in Blue Focus. The exchange differences of Blue Focus, affected by the changes in foreign exchange rates of overseas operation, in OCI items was -129.39million in 2015 and -126.15 million in 2016, while the net income of Blue Focus is only 9.37 million Yuan in 2016, which meant a major potential impact on the company's net income.

Thus, when carrying out all-sided financial analysis for the listed companies, it is necessary to identify whether the listed companies transfer the exchange differences from OCI in financial statements into gains and losses in current period through the disposal of overseas operations, so as to adjust and manage current gain and loss.

\section{The portion of the gain or loss on cash flow hedge}

There are three types of hedging based on hedging risk: fair value hedge, cash flow hedge and Hedge of a net investment in a foreign operation according to CAS24. For a fair value hedge, the gain 
or loss on the hedging instrument is recognized in profit or loss. For a cash flow hedge, the portion of the gain or loss on the hedging instrument that is determined to be an effective hedge is recognized in OCI.

On the one hand, the classification of hedges has effects on earnings management. Although the notions of fair value hedge and cash flow hedge differ significantly, the boundaries of the two hedges are sometimes not clear enough in the actual operation (Zhu, 2010). The classification depends on the strategy of enterprise risk management and the intention of managers because the guidelines have crossings and unclear boundaries, leaving space for earnings management. On the other hand, the effective portion of cash flow hedges is recognized in OCI, to a certain extent, hides managers' decision-making errors. It will increase the risk of the enterprise and lead to huge loss if there is improper operation or only for the speculative arbitrage. Loss of hedge indicates that the managers have made wrong judgments on expectations and the reorganization of OCI cannot directly reflect the outcome of managements, which will confuse shareholders.

Based on the industry characteristics, special attention needs to be paid to the effective portion of gains and losses on hedging instruments in a cash flow hedge in OCI, for financial analysis and earnings management identification in industries such as non-ferrous metals and aviation.

Yunnan Copper bought standard copper cathode futures contracts on the Shanghai Futures Exchange to hedge against the risk of fluctuations in the expected future cash flows. In the copper cathode commodity futures contract purchased by Yunnan Copper in 2015, there was a floating loss of -289 million for the hedging instrument, and its net income was only 64 million Yuan in the same year. If the loss is recognized in the current profit or loss, Yunnan Copper will turn profit into loss.

\section{Conclusion}

The results of this study enrich the literature research of OCI as well as earnings management. It provides evidence that OCI is regarded as earnings management tool from listed company cases by Chinese managers, who concealed losses by recording into OCI in current period or adjusted asset liability ratio by recognizing outside of gain or loss to achieve specific purpose. What's more, some components of income and expense to be included in OCI instead of profit or loss can temporarily cover up the wrong decisions of managers, causing illusions to stakeholders. It aggravates the information asymmetry and the agency problem, endangering the development of the company and the growth of the wealth of the shareholders in the long term.

Noticeably, the findings of our study are significant for accounting standard setters, for OCI has potential earnings management opportunities and may be manipulated by managers. Besides, it is also important for outside investors and analysts to assess the performance of the company by reviewing the earnings figures showed in the financial reports. The users of financial reports should pay attention to not only traditional earnings indicators such as net income, but also the OCI and comprehensive income, especially potential impact on current profits and losses in OCI when reclassified. Future research will utilize a large sample to test the effect of OCI in earnings management with more available data and empirical research methods.

\section{References}

[1] Yang Kezhi. Other Comprehensive Income, Information Transparency and Earnings Management [J]. Journal of Central University of finance \& Economics, 2016(08):65-73. (in Chinese)

[2] Barth, M. E., Gómez Biscarri, J., Kasznik, R. and López-Espinosa, G. 2014, Bank earnings and regulatory capital management using available for sale securities, Available at SSRN 2448482.

[3] Wang Jue. Research into Earnings Management of Chinese Listed Companies with Investment Income from Financial Instruments [J]. Finance Forum, 2012,17(01):52-56. (in Chinese)

[4] Zhu Lin. Analysis of the influence of hedging accounting standards on enterprise earnings management [J]. Modern Accounting, 2010(02):32-33+22. (in Chinese) 